\title{
The Effects of Thai Herbal Ha-Rak Formula on COX Isoform Expression in Human Umbilical Vein Endothelial Cells Induced by IL-1 $\beta$
}

\author{
Titchaporn Palo, ${ }^{1}$ Athiwat Thaworn, ${ }^{1}$ Phornnapa Charoenkij, ${ }^{1}$ \\ Onusa Thamsermsang, ${ }^{2}$ Sirikul Chotewuttakorn, ${ }^{1}$ Pinpat Tripatara, ${ }^{1}$ \\ Tawee Laohapand, ${ }^{2}$ and Pravit Akarasereenont ${ }^{1,2}$ \\ ${ }^{1}$ Department of Pharmacology, Faculty of Medicine, Siriraj Hospital, Mahidol University, Bangkok 10700, Thailand \\ ${ }^{2}$ Center of Applied Thai Traditional Medicine, Faculty of Medicine, Siriraj Hospital, Mahidol University, Bangkok 10700, Thailand
}

Correspondence should be addressed to Pravit Akarasereenont; pravit.auk@mahidol.ac.th

Received 26 August 2017; Accepted 27 September 2017; Published 29 October 2017

Academic Editor: Youn C. Kim

Copyright (c) 2017 Titchaporn Palo et al. This is an open access article distributed under the Creative Commons Attribution License, which permits unrestricted use, distribution, and reproduction in any medium, provided the original work is properly cited.

\begin{abstract}
Objective. To investigate the modulated effects of HRF on cyclooxygenase isoform expression and its activity, using the human umbilical vein endothelial cell (HUVEC) model induced by interleukin-1 beta (IL-1 $\beta$ ). Methods. Cells were treated with indomethacin (positive control), HRF, and its components at various concentrations prior to treatment with IL- $1 \beta$ at $24 \mathrm{~h}$. Cell viability was determined by MTT assay. Moreover, the anti-inflammatory effects of HRF and its components through mRNA and protein expression were established using real-time quantitative PCR and Western blot, respectively. COX activity was identified via exogenous and endogenous $\mathrm{PGE}_{2}$ productions using the EIA. Result. There was no cytotoxicity in HUVECs treated with HRF. None of the experimental conditions used in the study affected the expression of COX-1, but COX-2 protein expression was inhibited at concentrations under $10 \mu \mathrm{g} / \mathrm{mL}$. Despite the significantly increased levels of exogenous PGE 2 , HRF had no effect on COX-2 mRNA expression. However, the production of $\mathrm{PGE}_{2}$ was lower at a concentration of $100 \mu \mathrm{g} / \mathrm{mL} \mathrm{HRF}$ than at a concentration below $10 \mu \mathrm{g} / \mathrm{mL}$. Interestingly, each component of HRF revealed different effects of the Ha-Rak formula. Conclusion. Our preliminary findings suggest that HRF and its components provide diverse modulation of COX-2 and $\mathrm{PGE}_{2}$ at the in vitro level.
\end{abstract}

\section{Introduction}

Fever, an excessively high body temperature, is a defensive mechanism of humans and is found as a clinical sign of inflammation [1]. Numerous endogenous and exogenous factors trigger a febrile response and lead to the release of various inflammatory mediators from immune and nonimmune cells, such as leukocytes, macrophages, and endothelial cells $[2,3]$. These cells play an essential role in generating several proinflammatory cytokines, namely, interleukin-1 (IL-1), interleukin-6 (IL-6), tumor necrosis factors (TNF), and interferons (IFNs), which act as inflammatory inducers in a febrile response [4-6].
IL-1, a proinflammatory cytokine, is a one of the endogenous pyrogens (EPs) implicated in fever induction. EPs are able to circulate in the blood vessels and activate prostaglandin E2 $\left(\mathrm{PGE}_{2}\right)$ synthesis in the brain via cAMP and other neurotransmitter activation, resulting in an elevation of the thermostatic set point and, in turn, an increase in heat loss and temperature [4, 7]. Moreover, IL-1 is also involved in the synthesis of prostaglandins (PGs) and lipid eicosanoids through cyclooxygenase enzyme (COX) activity. $\mathrm{COX}$ is a key enzyme that present two isoforms (COX-1 and COX-2), both of which act as rate-limiting enzymes in PG biosynthesis by metabolizing arachidonic acid. COX-1 is commonly expressed in various cells and 
TABLE 1: List of primer sequences.

\begin{tabular}{lccc}
\hline Primer name & GenBank & Sense primer $\left(5^{\prime} \rightarrow 3^{\prime}\right)$ & Anti-sense primer $\left(5^{\prime} \rightarrow 3^{\prime}\right)$ \\
\hline COX-1 & NM_001271368.1 & GACCCGCCTCATCCTCATAG-3 & CCACCGA TCTTGAAGGAGTCA \\
COX-2 & NM_006662.2 & CAAAAGCTGGGAAGCCTTCT & CCATCCTTGAAAAGGCGCAG \\
GAPDH & NM_001289746.1 & GACCACTTTGTCAAGCTCATTTCC & TGAGGGTCTCTCTCTTCCTCTTGT \\
\hline
\end{tabular}

COX-1: cyclooxygenase-1; COX-2: cyclooxygenase-2; GAPDH: glyceraldehyde-3-phosphate dehydrogenase.

tissues and facilitates housekeeping functions, whereas COX2 is induced by proinflammatory cytokines, growth factors, infections, and other harmful stimuli. Additionally, COX2 is one of the inflammatory markers, and it is associated with fever-related diseases [8-10]. In clinical practice, nonsteroidal anti-inflammatory drugs (NSAIDs), such as aspirin, indomethacin, diclofenac, and ibuprofen, are usually used to block COX activities and attenuate inflammatory responses, including fever $[11,12]$. However, some toxicological effects stemming from the prolonged use of NSAIDs can cause side effects, such as hepatotoxicity, gastrointestinal irritation, renal impairment, and allergic reactions $[13,14]$.

Thai herbal Ha-Rak formula (HRF), also known as Bencha-Loga-Wichienis, is a polyherbal formula consisting of the roots of five medical plants: Capparis micracantha DC. (CM), Clerodendrum petasites S. Moore (CP), Harrisonia perforate Merr. (HP), Ficus racemosa L. (FR), and Tiliacora triandra Diels (TT). It has been traditionally used as an antipyretic and anti-inflammatory drug for fever treatment, and it is included in the National List of Essential Medicines of Thailand. Previous in vitro and in vivo studies have indicated that HRF shows diverse pharmacological effects, including antioxidant, [15] anti-inflammatory [16], antipyretic and antinociceptive properties [17]. Additionally, certain components of HRF, namely, the extracts from FR and CP, have been shown to exert anti-inflammatory and antipyretic effects [18-20]. Nevertheless, the modulated effects of HRF on COX activity and prostaglandin synthesis are still imprecise and need clarification. We therefore investigated the regulation of HRF and its components on COX inhibition, using IL$1 \beta$ induced in the human umbilical vein endothelial cell (HUVEC) model.

\section{Materials and Methods}

2.1. Reagents. All powders of HRF and its components were prepared by the Manufacturing Unit of Herbal Medicines and Products Ayurved Siriraj, Center of Applied Thai Traditional Medicine, Faculty of Medicine, Siriraj Hospital, Mahidol University. The human endothelial-SFM basal growth medium with L-glutamine was obtained from Gibco (Gibco, USA). The human COX-1 and COX-2 monoclonal antibodies and standards were purchased from Cayman Chemical (Ann Arbor, MI, USA). The ethanol reagent was purchased from Scharlau (Scharlau, Spain). The fetal bovine serum (FBS), penicillin, streptomycin, indomethacin, and other chemical reagents were purchased from Sigma-Aldrich (MO, USA).
2.2. Preparation of HRF and Its Component Extracts. The herbal powders were extracted with an $80 \%$ ethanol solution at a ratio of $1: 10(\mathrm{w} / \mathrm{v})$. All of the HRF and its component extractions were evaporated under $40^{\circ} \mathrm{C}$ at a pressure within 110-180 mbar (Buchi, Switzerland) and kept in a minus $80^{\circ} \mathrm{C}$ freezer prior to lyophilization. The freeze-dried extracts were stored in the dark in a controlled temperature and humidity environment.

\subsection{Human Umbilical Vein Endothelial Cell Isolation and} Treatment. HUVECs were derived from umbilical cords obtained from normal, pregnant women, as previously described [21]. The isolated HUVECs were cultured in T-75 flasks with human endothelial-SFM basal growth medium and with L-glutamine (Gibco, USA) supplemented with fetal bovine serum $10 \%$ (FBS), penicillin $(100 \mathrm{U} / \mathrm{mL})$, and streptomycin $(100 \mathrm{mg} / \mathrm{mL})$, at $37^{\circ} \mathrm{C}$ in $5 \% \mathrm{CO}_{2}$ in an incubator. When the cells were over $80 \%$ confluent, the HUVECs were treated with indomethacin $(100 \mu \mathrm{g} / \mathrm{mL}), \mathrm{HRF}$, and its component extracts at various concentrations prior to treatment with IL-1 $\beta(1 \eta \mathrm{g} / \mathrm{mL})$; they were subsequently incubated at $37^{\circ} \mathrm{C}$ in $5 \% \mathrm{CO}_{2}$ for $24 \mathrm{~h}$.

2.4. Cell Viability Assay. MTT assay, as previously described [22], was conducted to determine the cytotoxicity of the test compounds. Briefly, HUVECs $\left(3 \times 10^{4}\right.$ cells/well $)$ were seeded on a 96-well plate and pretreated with HRF and the component extracts $(0.00001-100 \mu \mathrm{g} / \mathrm{mL})$ for $24 \mathrm{~h}$; after that, $200 \mu \mathrm{L}$ of MTT $(200 \mu \mathrm{g} / \mathrm{mL})$ was added to each well and incubated for $1 \mathrm{~h}$. To dissolve formazan, $100 \mu \mathrm{L}$ of DMSO solution was added to each well and measured using a spectrophotometer (SpectraMAX M5, Molecular Devices, CA) at an absorbance of $595 \mathrm{~nm}$.

2.5. Real-Time Quantitative PCR Analysis ( $q R T-P C R)$. The total RNA from each treatment was extracted with an Illustra RNA spin Mini RNA isolation kit (GE Healthcare, UK). All of the primer sequences are described in Table 1 . The conditions are $95^{\circ} \mathrm{C}$ for $10 \mathrm{~min}$ and $95^{\circ} \mathrm{C}$ for $15 \mathrm{~min}$, followed by 40 cycles of amplification at $60^{\circ} \mathrm{C}$ for $40 \mathrm{~min}$, and, subsequently, at $72^{\circ} \mathrm{C}$ for $40 \mathrm{~min}$. Analysis of the data was performed with the cycle threshold (Ct) method $(\Delta \Delta \mathrm{Ct})$, normalized with the GAPDH gene used as a housekeeping gene and internal control. 
2.6. Western Blot Analysis. HUVECs were treated with indomethacin, HRF, and the extracts $(1,10$, and $100 \mu \mathrm{g} / \mathrm{mL})$ prior to IL- $1 \beta(1 \eta \mathrm{g} / \mathrm{mL})$ stimulation for $24 \mathrm{~h}$. The COX determination, including a Bradford protein assay, was performed as previously described [21]. Briefly, all samples were loaded into SDS-PAGE, underwent electrophoresis, and were transferred to nitrocellulose blotting membranes (BioRad, Germany). After blocking with a solution of 5\% skim milk for $1.5 \mathrm{~h}$ at room temperature, the membranes were incubated overnight with a specific monoclonal COX-1 or COX-2 antibody at $4^{\circ} \mathrm{C}$ and an anti-mouse IgG of COX-1 or anti-COX-2 (Sigma-Aldrich, USA, dilution 1/10000) for $1.5 \mathrm{~h}$, respectively. $\beta$-Actin (Sigma-Aldrich, USA, dilution 1/5000) was used as an internal control in the experiment. The COX protein bands were visualized using VersaDoc ${ }^{\mathrm{TM}}$ Imaging Systems (Bio-Rad, Germany).

2.7. Determination of COX Activity. After treating the cells with the test compounds, the supernatant of each sample was collected after $24 \mathrm{~h}$ to measure the endogenous level of $\mathrm{PGE}_{2}$. To determine the exogenous $\mathrm{PGE}_{2}$ production, the medium from the HUVEC culture was discarded. The cells were washed with a phosphate-buffered saline (PBS) solution (138 mM NaCl; $2.7 \mathrm{mM} \mathrm{KCl,} 8 \mathrm{mM} \mathrm{Na} \mathrm{HPO}_{4}$; and $1.46 \mathrm{mM}$ $\mathrm{KH}_{2} \mathrm{PO}_{4}$ ), incubated with a medium containing arachidonic acid $(10 \mu \mathrm{M})$ for $10 \mathrm{~min}$. The level of $\mathrm{PGE}_{2}$ was measured by using an enzyme immunoassay kit (GE Healthcare, UK).

2.8. Statistical Analysis. Data were presented as mean \pm standard error of the mean (SEM). All experiments were performed in triplicate, and their results were analyzed by one-way analysis of variance (ANOVA), followed by Dunnett's post hoc test using GraphPad Prism version 5 for Windows (GraphPad Software Inc., San Diego, CA, USA). The statistically significantly value was set at $p<0.05$.

\section{Results}

3.1. Cell Viability Assessments. The HUVECs were treated with HRF and its components at the increasing concentrations of $0.0001,0.001,0.01,0.1,1,10$, and $100 \mu \mathrm{g} / \mathrm{mL}$ (data not shown). At $100 \mu \mathrm{g} / \mathrm{mL}$, the cell viabilities were higher than $90 \%$, except for the cells treated with Ficus racemosa L. (Table 2). This result suggests that no obvious cytotoxicity was observed in the HUVECs incubated with HRF at up to $100 \mu \mathrm{g} / \mathrm{mL}$.

3.2. Inhibitory Effects of HRF and Its Components on COX $m R N A$ Expression. The results demonstrated that IL$1 \beta(1 \eta \mathrm{g} / \mathrm{mL})$ significantly increased the COX1 and COX2 mRNA expressions, relative to the untreated group of HUVECs $(p<0.05)$. Treatment with or without indomethacin $(100 \mu \mathrm{g} / \mathrm{mL})$ in the IL- $1 \beta$-induced HUVECs significantly attenuated the mRNA expressions of COX-1 and COX-2 $(p<0.05$; Figures 1 and 2$)$.
TABLE 2: Cell viability of $100 \mu \mathrm{g} / \mathrm{mL}$ of HRF and its components against HUVECs.

\begin{tabular}{lc}
\hline Herbal & Cell viability (\%) \\
\hline Thai herbal Ha-Rak formula & $94 \pm 5$ \\
Harrisonia perforate Merr. & $120 \pm 4$ \\
Capparis micracantha DC. & $125 \pm 3$ \\
Clerodendrum petasites S. Moore & $99 \pm 2$ \\
Ficus racemosa L. & $58 \pm 4$ \\
Tiliacora triandra Diels & $99 \pm 4$ \\
\hline
\end{tabular}

The data represent mean \pm SEM of triplicate wells from at least 3 separate experiments performed on different days.

Furthermore, treatment with the $\operatorname{HRF}(1,10 \mu \mathrm{g} / \mathrm{mL})$, TT $(100 \mu \mathrm{g} / \mathrm{mL})$, and $\mathrm{FR}(1,10$, and $100 \mu \mathrm{g} / \mathrm{mL})$ extracts prior to the IL- $1 \beta$ challenge suppressed the COX- 1 mRNA expression, with the FR extracts showing an inhibitory effect on COX-1 in a dose-dependent manner (Figures 1(a), 1(b), 1(e), and 1(f)). In addition, the highest dose of the FR extract $(100 \mu \mathrm{g} / \mathrm{mL})$ provided the greatest inhibition of COX-2 mRNA expression induced by IL- $1 \beta$ stimulation (Figure $2(\mathrm{e})$ ). However, the other treatment compounds (HRF, HP, CM, TT, and CP extracts) showed a tendency to decrease the COX-2 mRNA levels in HUVECs induced by IL-1 $\beta$ (Figures 2(a), 2(b), 2(c), and $2(\mathrm{~d}))$.

\subsection{HRF and Its Components Attenuated COX Protein Expres-} sion. No statistically significant differences were observed in the COX-1 protein expression treated with HRF and its components prior to the IL-1 $\beta$ challenge (Figure 3 ).

IL-1 $\beta(1 \eta \mathrm{g} / \mathrm{mL})$ noticeably induced COX-2 expression $(p<0.05)$ compared to the control groups (Figure 4$)$. HRF ( 1 and $10 \mu \mathrm{g} / \mathrm{mL}$ ) and HP (1 and $10 \mu \mathrm{g} / \mathrm{mL})$ significantly decreased levels of COX-2 protein induced by IL$1 \beta$. However, the highest dose of HRF $(100 \mu \mathrm{g} / \mathrm{mL})$ and $\mathrm{HP}(100 \mu \mathrm{g} / \mathrm{mL})$ extracts remarkably affected COX-2 protein inhibition (Figures 4(a) and 4(b)).

3.4. Effects of HRF and Its Components on COX Activity through Endogenous and Exogenous $P G E_{2}$ Production. HRF $(100 \mu \mathrm{g} / \mathrm{mL}), \mathrm{HP}(100 \mu \mathrm{g} / \mathrm{mL}), \mathrm{CM}(100 \mu \mathrm{g} / \mathrm{mL})$, FR $(10$ and $100 \mu \mathrm{g} / \mathrm{mL}$ ), and TT (1 and $10 \mu \mathrm{g} / \mathrm{mL}$ ) extracts significantly restrained endogenous $\mathrm{PGE}_{2}$ production (Figures 5(a) $-5(\mathrm{c}), 5(\mathrm{e})$, and 5(f)). Meanwhile, HRF $(10 \mu \mathrm{g} / \mathrm{mL})$ and $\mathrm{CP}(10 \mu \mathrm{g} / \mathrm{mL})$ noticeably increased $\mathrm{PGE}_{2}$ accumulation (Figures 5(a) and 5(d)) in IL-1 $\beta$ induced HUVECs $(p<0.05)$.

As for exogenous $\mathrm{PGE}_{2}$ generation, the results indicated that all concentrations of the test compounds, including HRF and its components, significantly enhanced COX activity, whereas CP (10 and $100 \mu \mathrm{g} / \mathrm{mL})$ significantly restrained exogenous $\mathrm{PGE}_{2}$ production (Figure 6). 


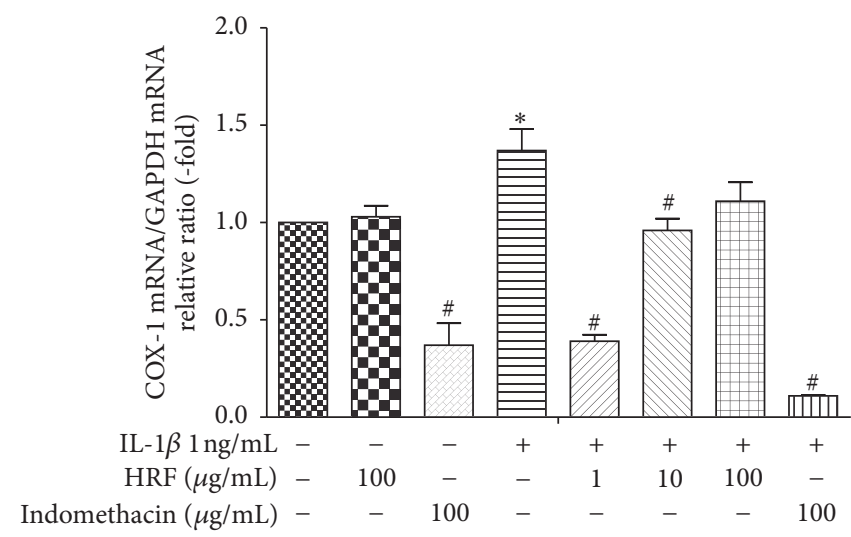

(a)

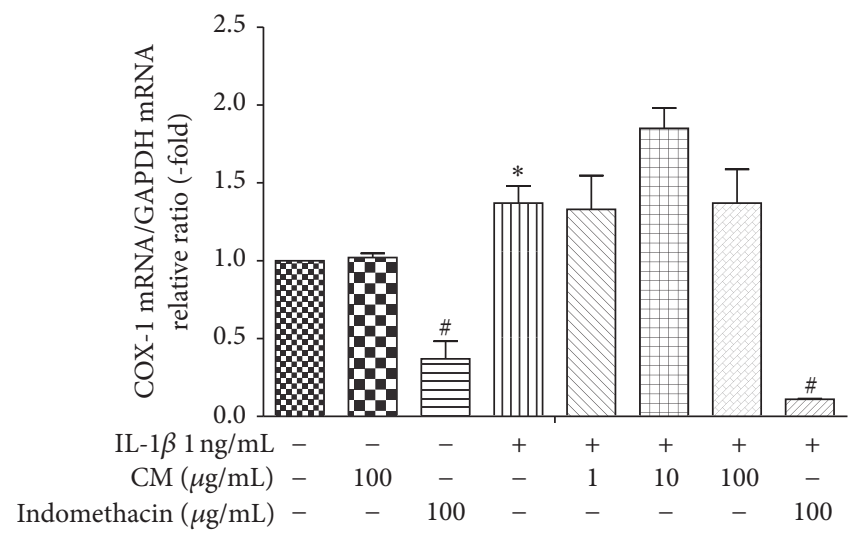

(c)

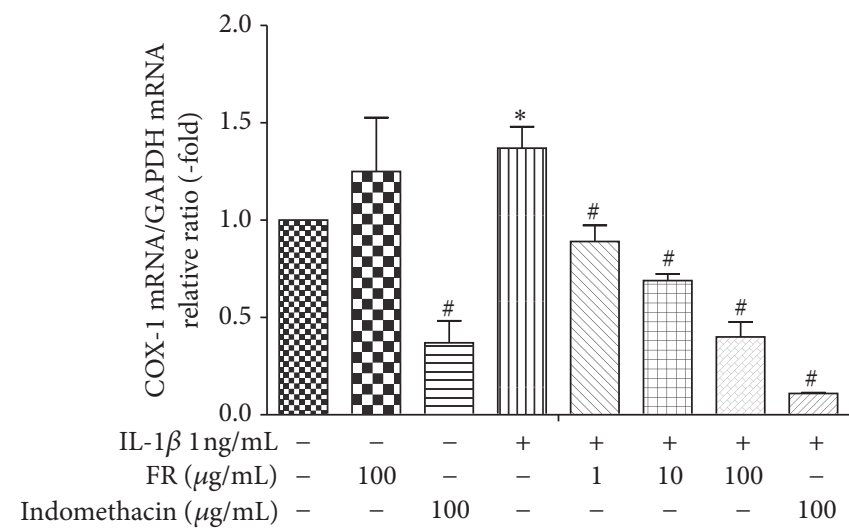

(e)

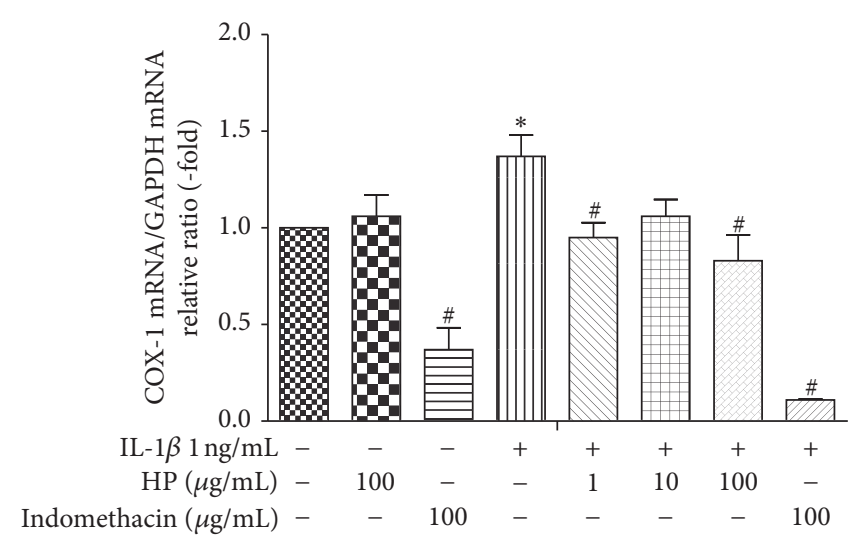

(b)

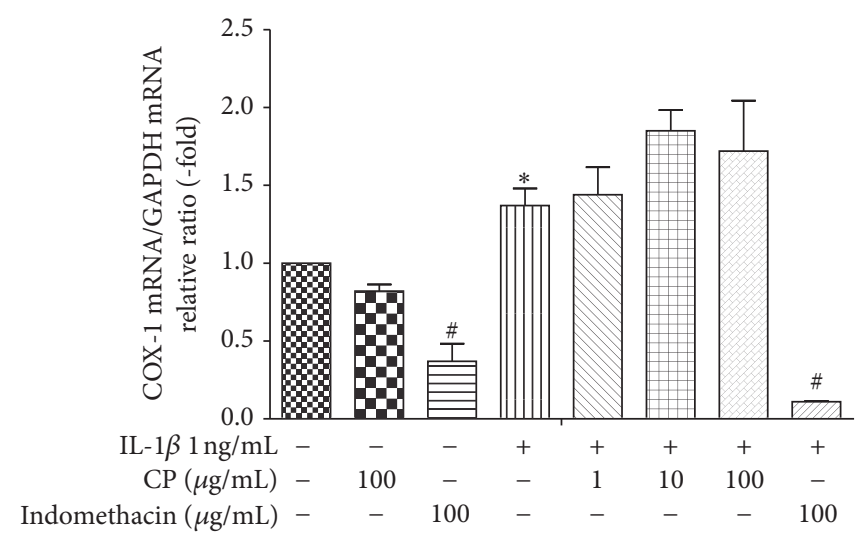

(d)

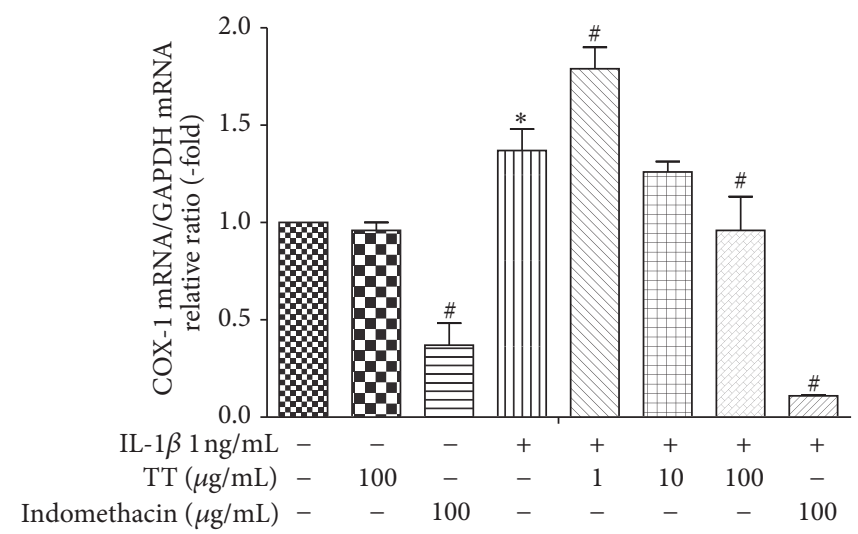

(f)

FIGURE 1: The effects of HRF (a) and its components: Harrisonia perforata Merr. (HP), Capparis micracantha DC. (CM), Clerodendrum petasites S. Moore (CP), Ficus racemosa L. (FR), and Tiliacora triandra Diels (TT) (b-f) (1, 10, and $100 \mu \mathrm{g} / \mathrm{mL})$ on COX-1 mRNA expression in HUVECs treated with IL- $1 \beta 1 \mathrm{ng} / \mathrm{mL}$ for $24 \mathrm{~h}$. Control: nonaddition. ${ }^{*} p<0.05$, versus control group; ${ }^{*} p<0.05$, versus IL- $1 \beta$ only.

\section{Discussion}

We have presented the modulatory effects of HRF and its components by focusing on the COX-PGE 2 pathway related to the febrile response in the HUVEC model. Several scientific reports have indicated that many cytokines and other mediators, including IL- $1 \beta$, play a critical role in fever induction through increased levels of $\mathrm{PGE}_{2}$ in the hypothalamic thermoregulatory center [23]. Moreover, the COX-PGE pathway is also responsible for inflammatory response development [24]. Cyclooxygenase enzymes (COXs), comprising two isoforms (COX-1 and COX-2), are the key enzymes in prostaglandin generation [25]. The induction of COX-2 by several proinflammatory cytokines represents an important mechanism controlling the overall production of prostanoids and the evolution of the inflammatory response [26]. Our results also confirm a previous report that IL-1 $\beta$ can activate 


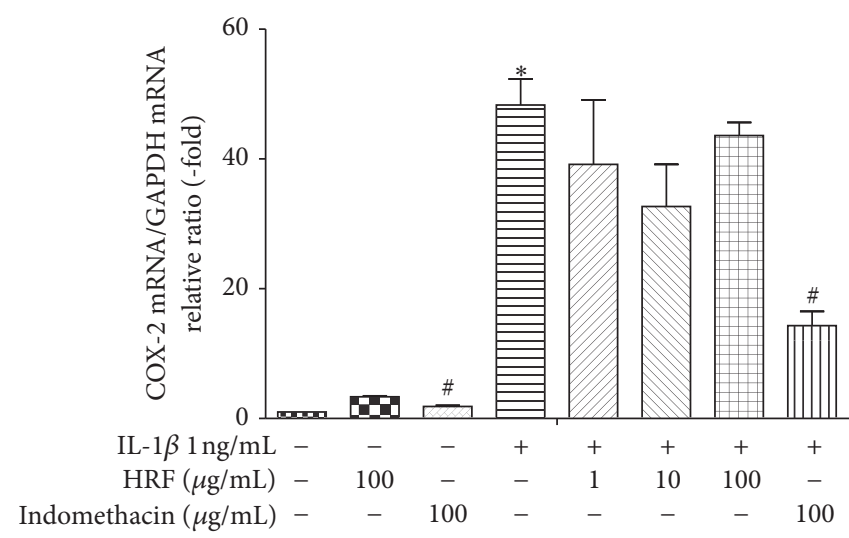

(a)

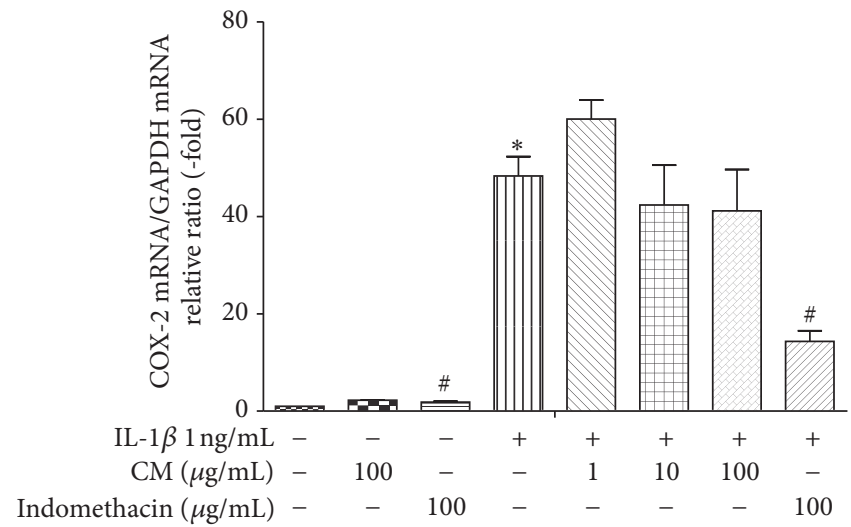

(c)

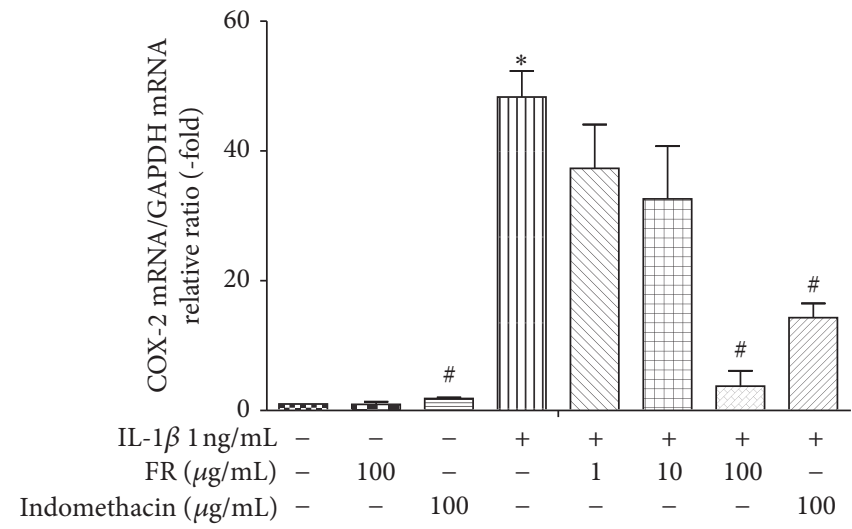

(e)

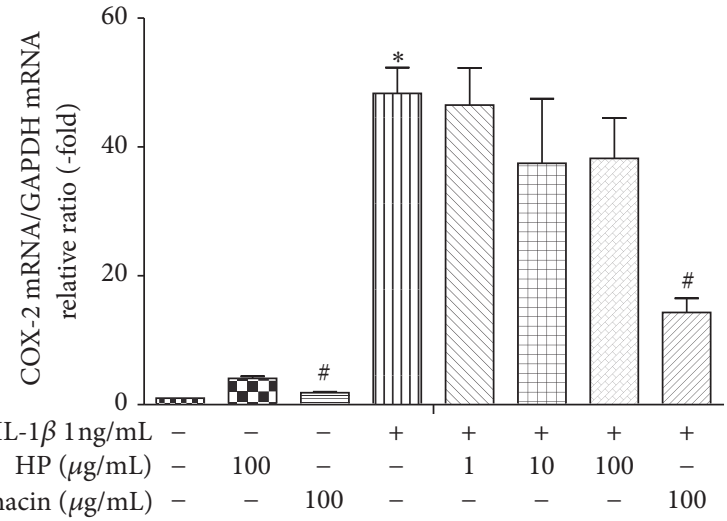

(b)

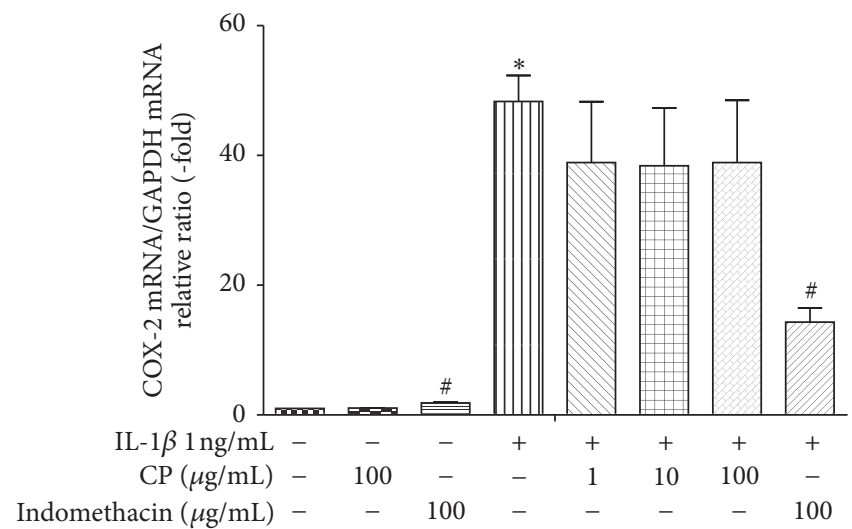

(d)

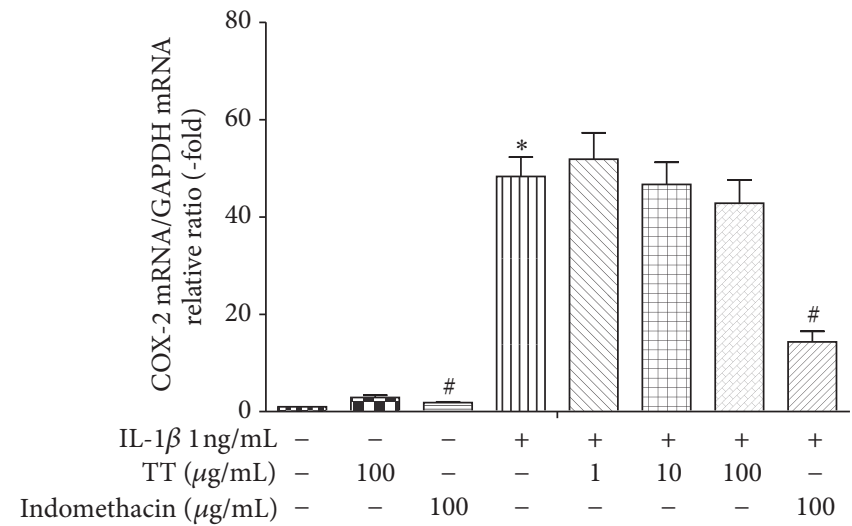

(f)

Figure 2: The effects of HRF (a) and its components: Harrisonia perforata Merr. (HP), Capparis micracantha DC. (CM), Clerodendrum petasites S. Moore (CP), Ficus racemosa L. (FR), and Tiliacora triandra Diels (TT) (b-f) $(1,10$, and $100 \mu \mathrm{g} / \mathrm{mL}) \mathrm{on}$ COX-2 mRNA expression in HUVECs treated with IL- $1 \beta 1 \mathrm{ng} / \mathrm{mL}$ for $24 \mathrm{~h}$ measured by qRT-PCR. Control: nonaddition. ${ }^{*} p<0.05$, versus control group; ${ }^{\#} p<0.05$, versus IL- $1 \beta$ only.

COX-2 mRNA and protein expressions and can consequently generate $\mathrm{PGE}_{2}$ production in the HUVEC model [27]. In this study, we also observed the effect of IL- $1 \beta$ on endogenous and exogenous $\mathrm{PGE}_{2}$ releases through COX-2 expression in HUVECs. We found that IL- $1 \beta$ could mediate endogenous and exogenous $\mathrm{PGE}_{2}$ production through COX-2 metabolites [26]. Thus, the anti-inflammatory effect is probably due to
IL-1 $\beta$ 's ability to inhibit the COX-2 enzyme [28]. After the endogenous $\mathrm{PGE}_{2}$ production was measured, exogenous $\mathrm{AA}$ was used to treat the cells. The amount of $\mathrm{PGE}_{2}$ measured in this media reflects the level of $\mathrm{PGE}_{2}$ synthesis by the exogenous AA and also the COX activity [29]. Interestingly, HRF significantly enhanced exogenous AA, leading to the 


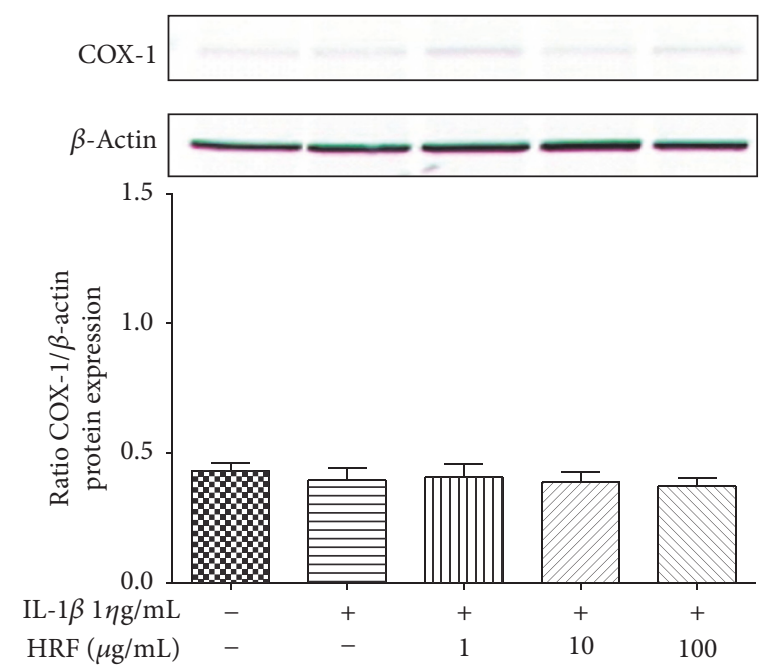

(a)

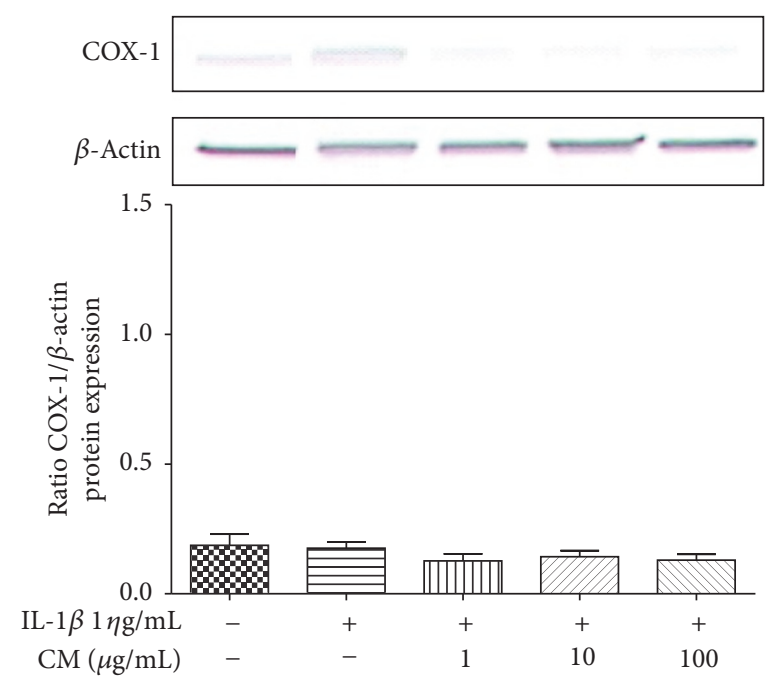

(c)

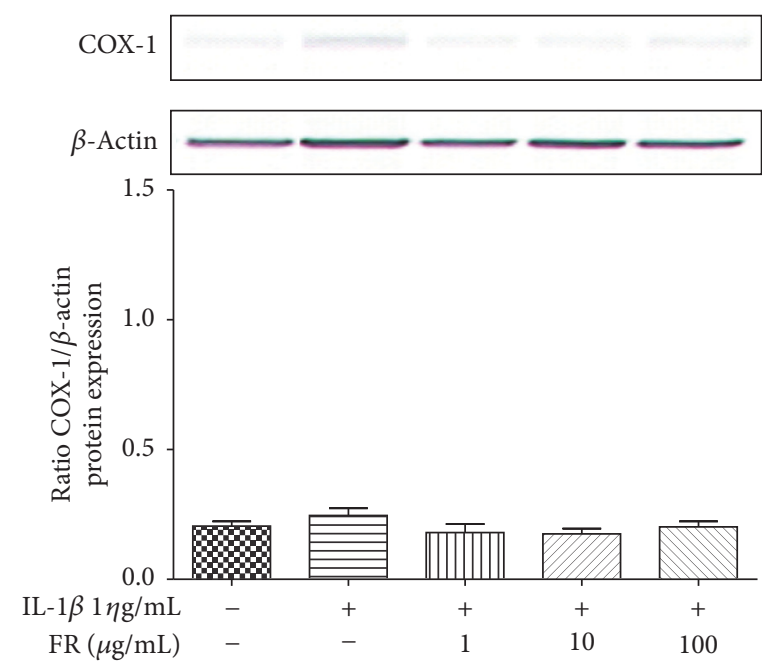

(e)

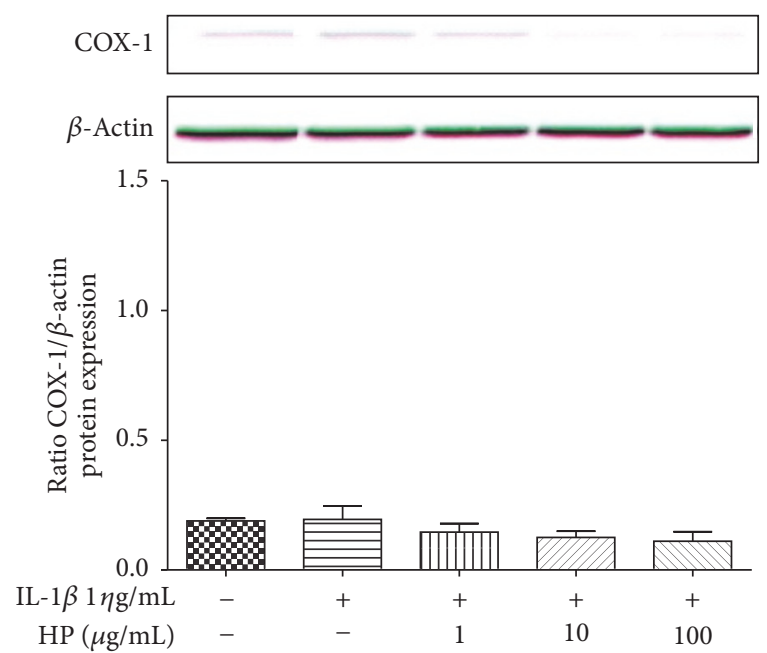

(b)

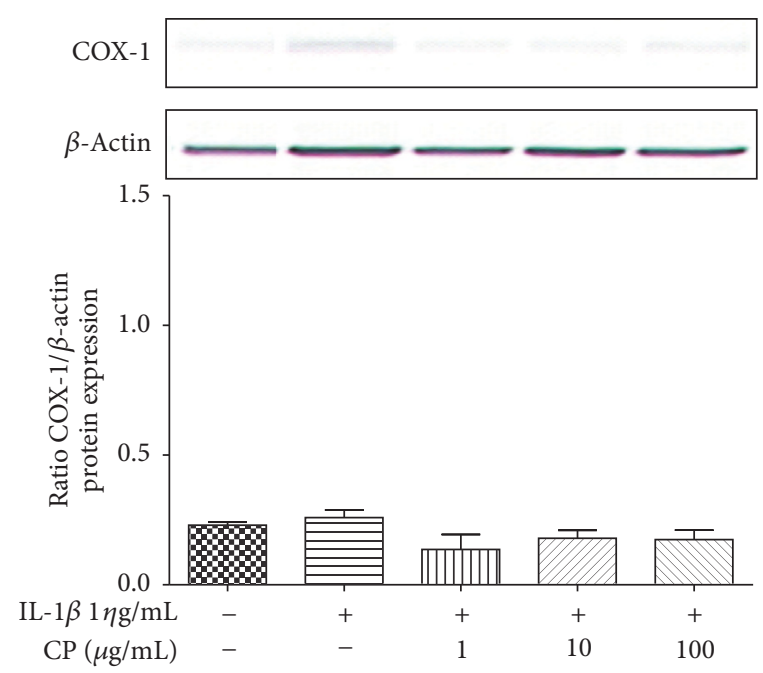

(d)

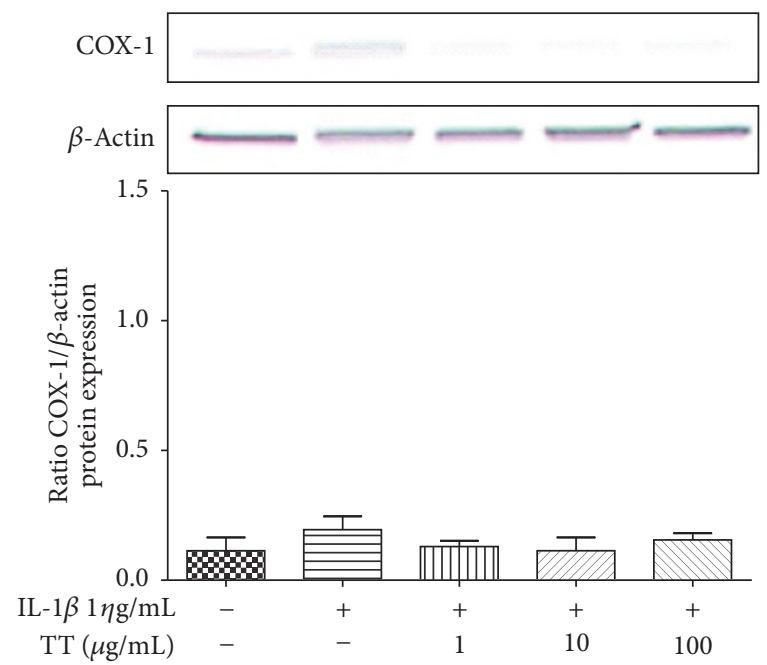

(f)

FIGURE 3: The effects of HRF (a) and its components: Harrisonia perforata Merr. (HP), Capparis micracantha DC. (CM), Clerodendrum petasites S. Moore (CP), Ficus racemosa L. (FR), and Tiliacora triandra Diels (TT) (b-f) on COX-1 protein expression in IL-1 $\beta$-treated HUVECs for $24 \mathrm{~h}$. COX protein was detected by Western blot. Control: nonaddition. 


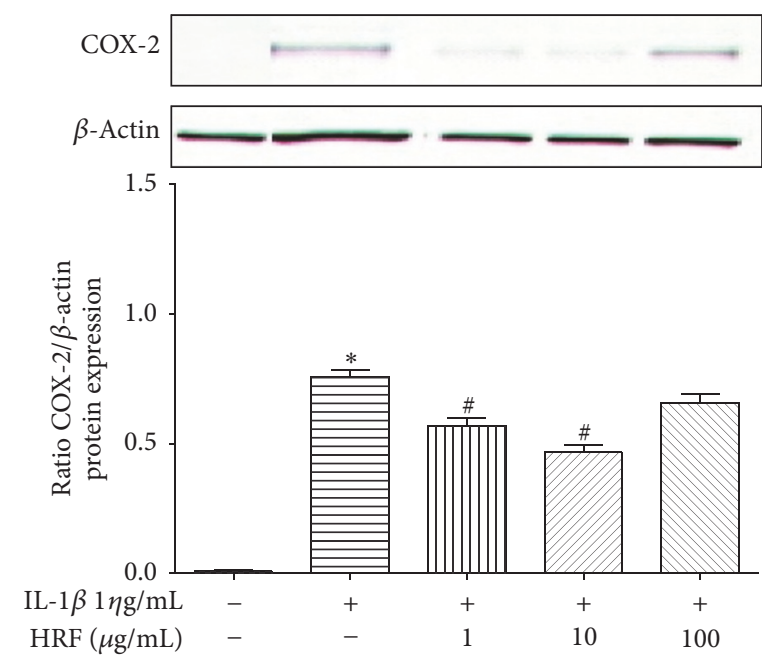

(a)

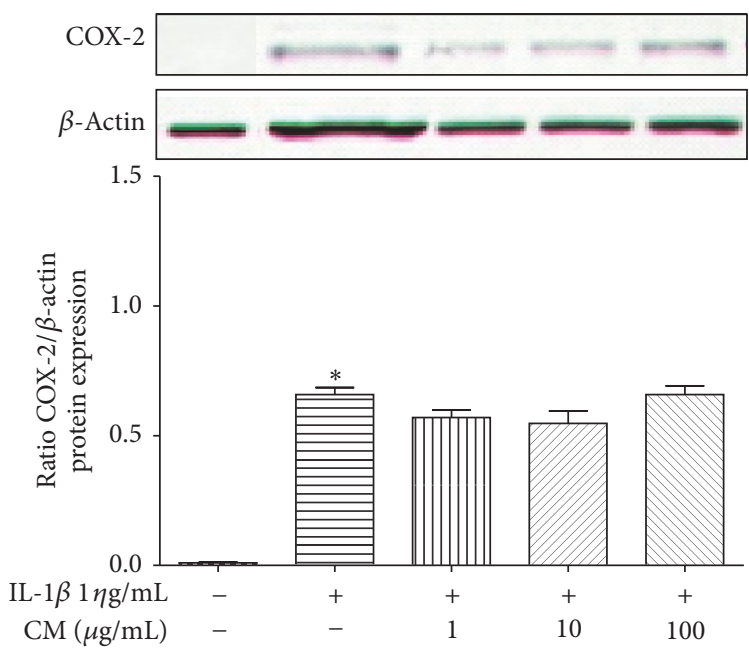

(c)

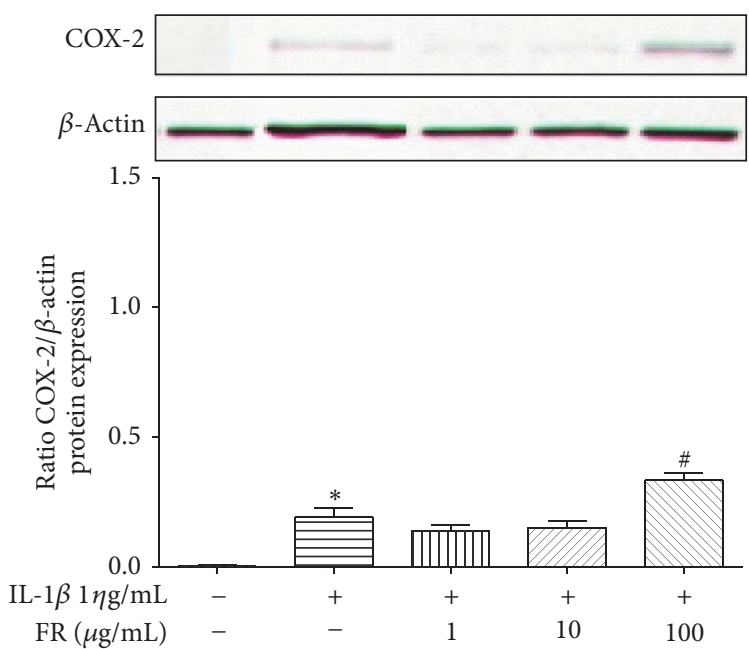

(e)

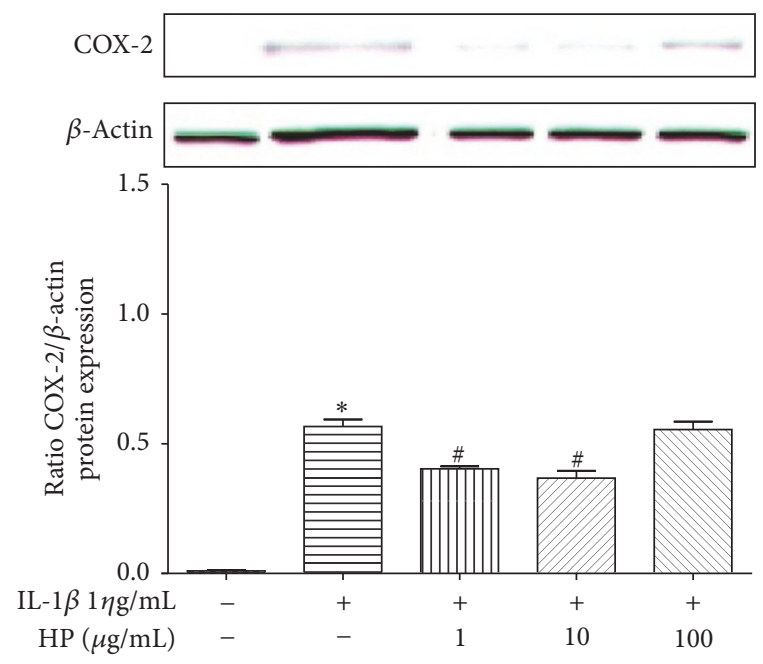

(b)

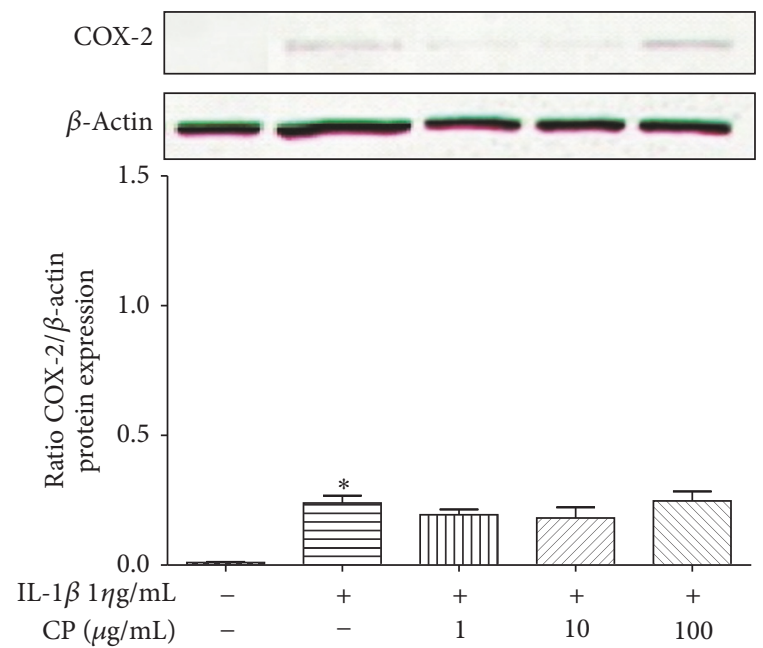

(d)

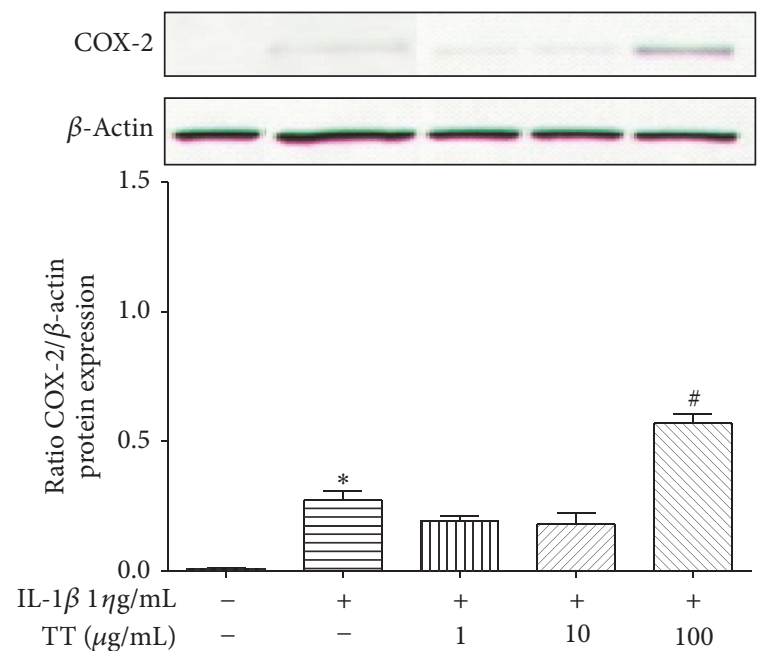

(f)

FIGURE 4: The effects of HRF (a) and its components: Harrisonia perforata Merr. (HP), Capparis micracantha DC. (CM), Clerodendrum petasites S. Moore (CP), Ficus racemosa L. (FR), and Tiliacora triandra Diels (TT) (b-f) on COX-2 protein expression in IL-1 $\beta$-treated HUVECs for $24 \mathrm{~h}$. COX protein was detected by Western blot. Control: nonaddition. ${ }^{*} p<0.05$, versus control group; ${ }^{\#} p<0.05$, versus IL- $1 \beta$ only. 


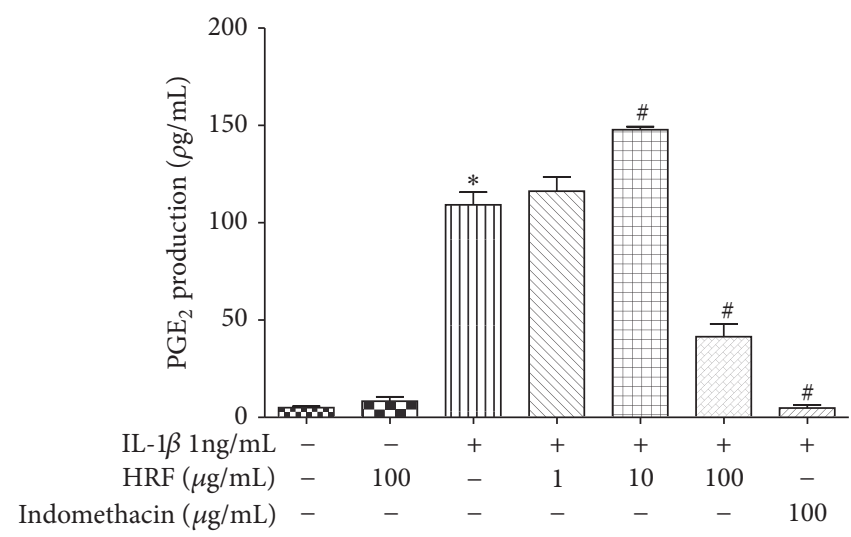

(a)

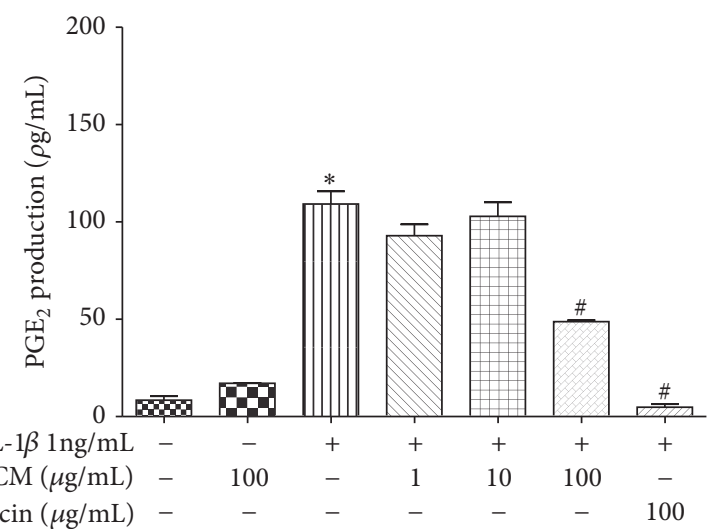

(c)

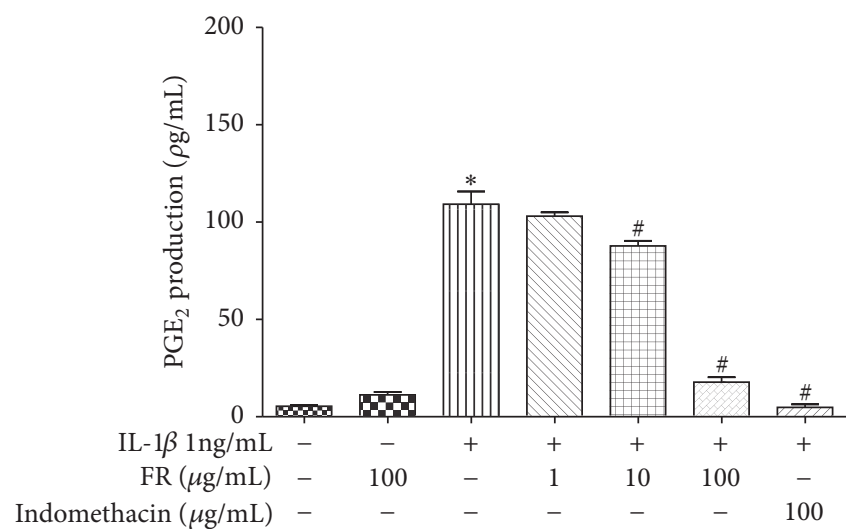

(e)

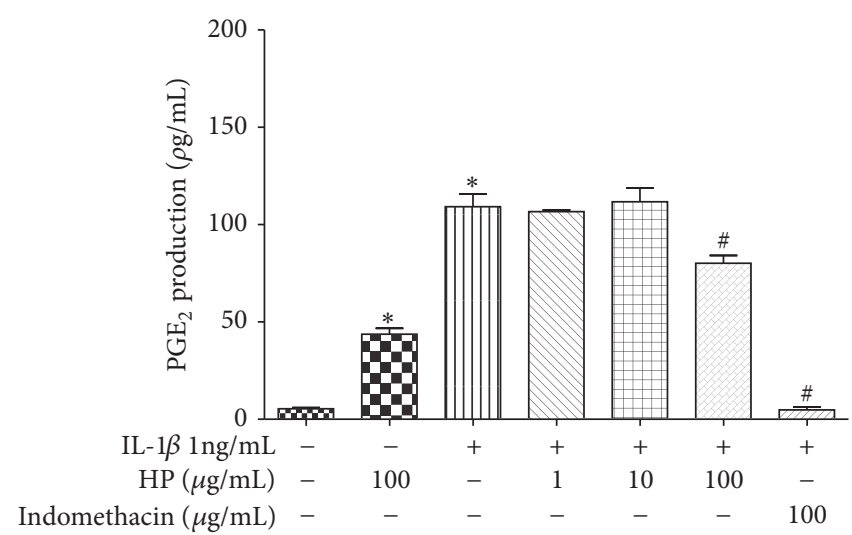

(b)

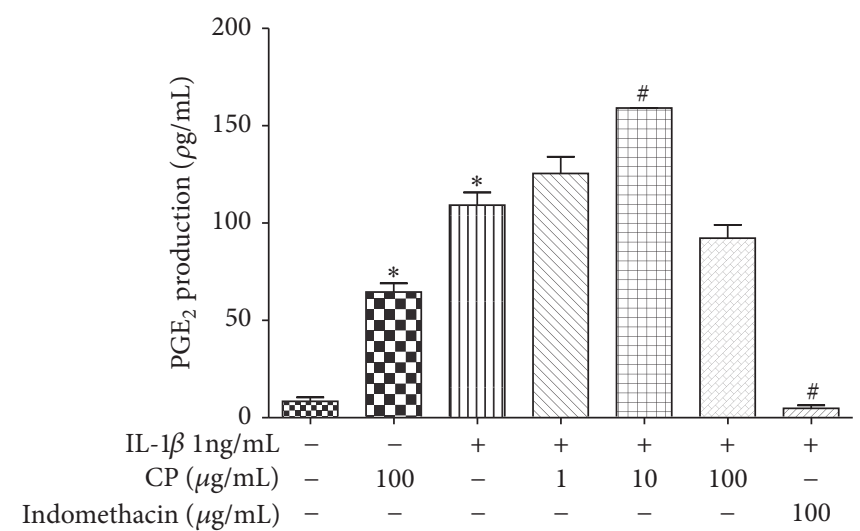

(d)

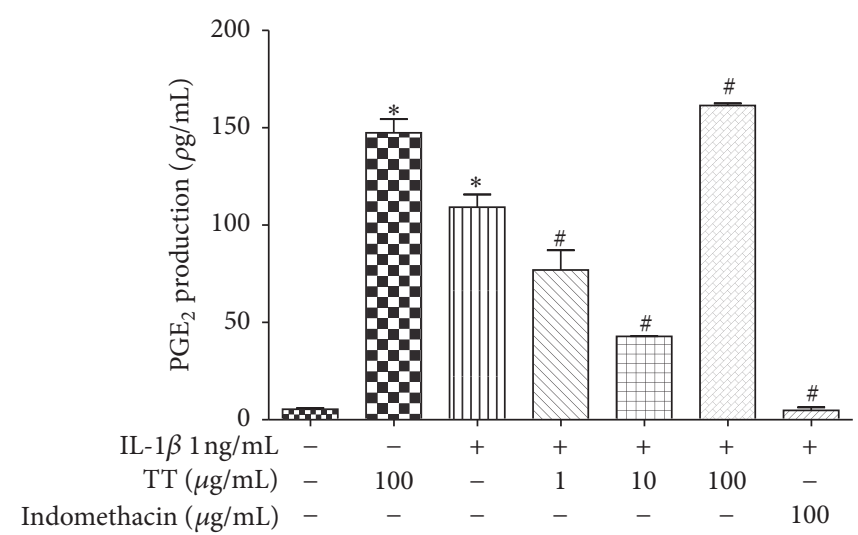

(f)

Figure 5: The effects of HRF (a) and its components: Harrisonia perforata Merr. (HP), Capparis micracantha DC. (CM), Clerodendrum petasites S. Moore (CP), Ficus racemosa L. (FR) and Tiliacora triandra Diels (TT) (b-f) on COX activity in the presence of endogenous AA in IL- $1 \beta$-treated HUVECs. The data represent mean \pm SEM of three experiments. Control: nonaddition. ${ }^{*} p<0.05$, versus control group; ${ }^{\#} p<0.05$, versus IL- $1 \beta$ only.

upregulation of COX-2 expression induced by IL-1 $\beta$ (Figure 6(a)). These results suggest that the use of exogenous AA as substrates will help to evaluate the COX enzyme directly [30].

In this study, HRF and its components did inhibit the COX-2 protein expression in HUVECs (Figure 4), but the amount of COX-1 protein expression was not affected. The predicted modulatory effects of HRF present in the protein clearly suggest its potential of being an inhibitor of COX-2. Our findings demonstrate that the formula and some components can modulate COX isoforms, as found in previous reports; for instance, Clerodendrum petasites S. Moore showed an inhibition of COX-2-mediated. $\mathrm{PGE}_{2}$ production in vitro [31] and a bioassay-guided fractionation of the ethanol extract of Ficus racemosa L. showed potent 


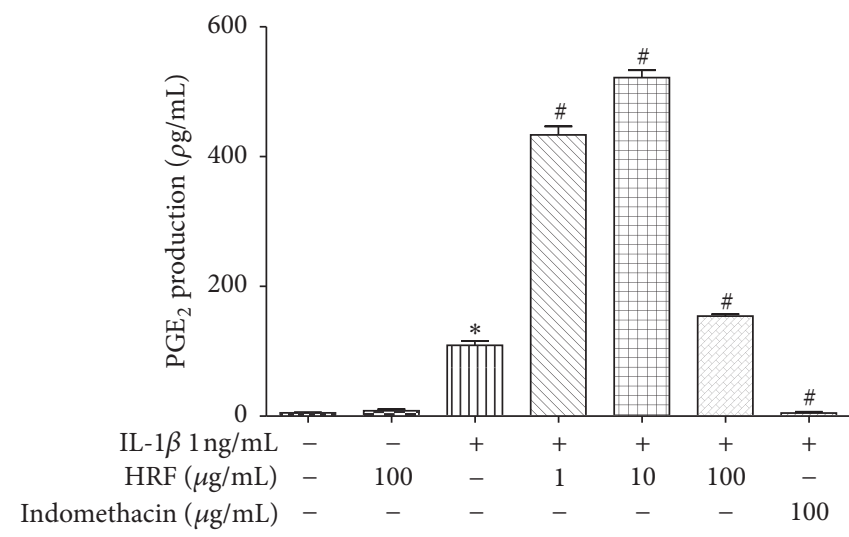

(a)

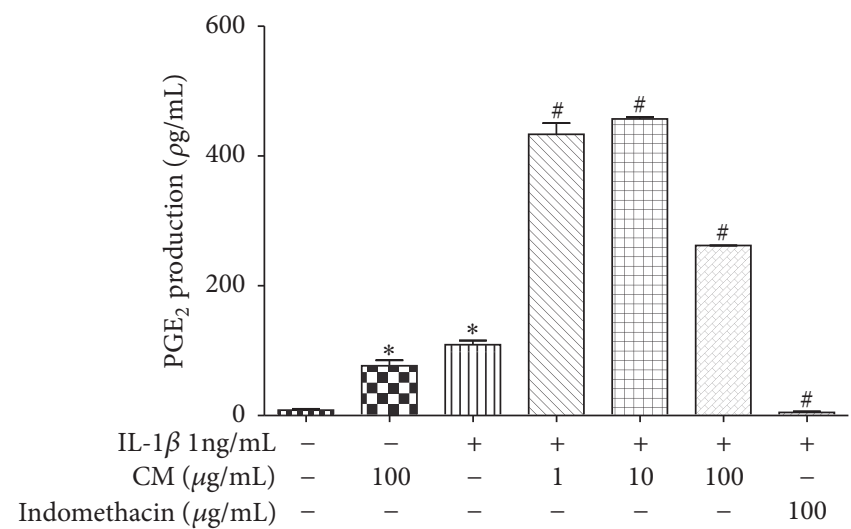

(c)

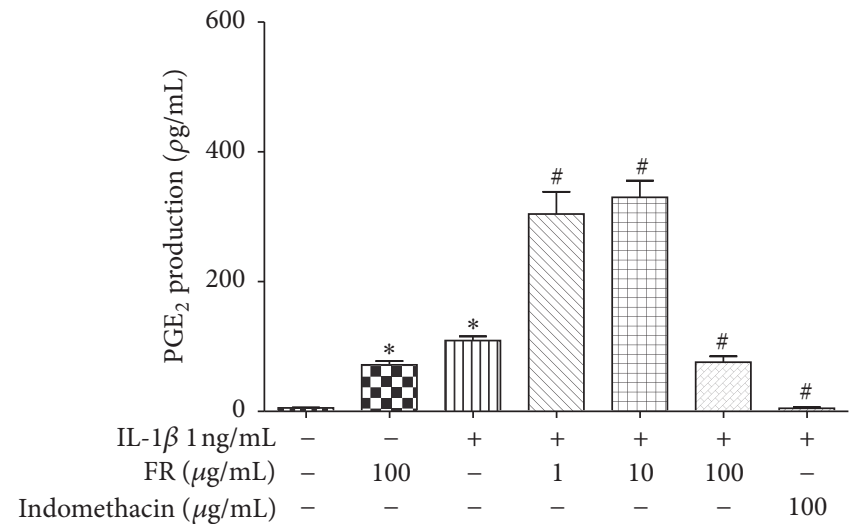

(e)

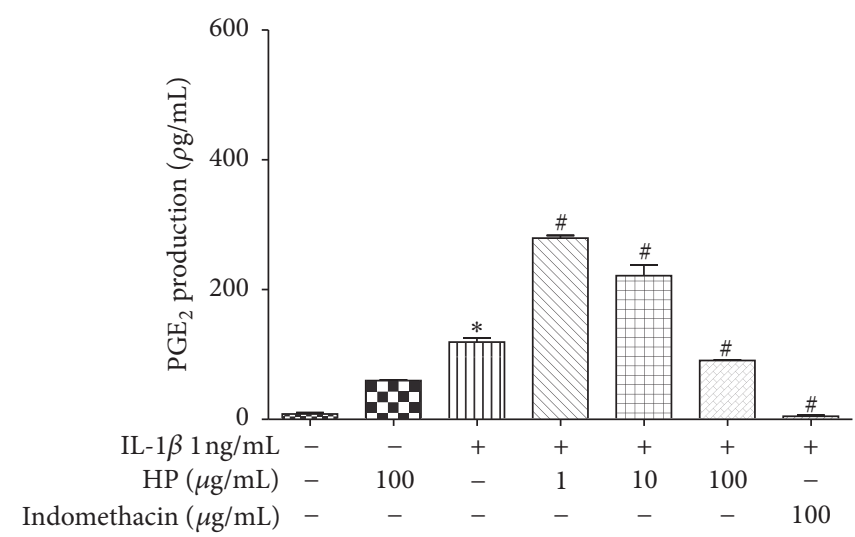

(b)

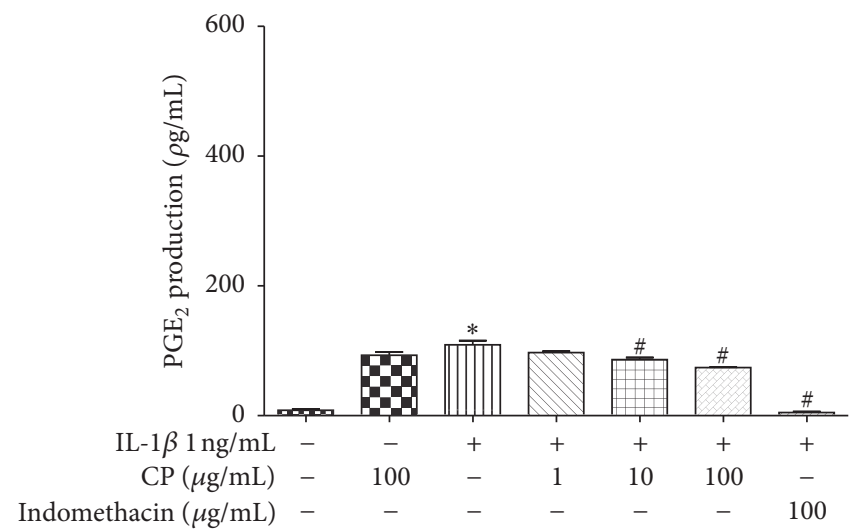

(d)

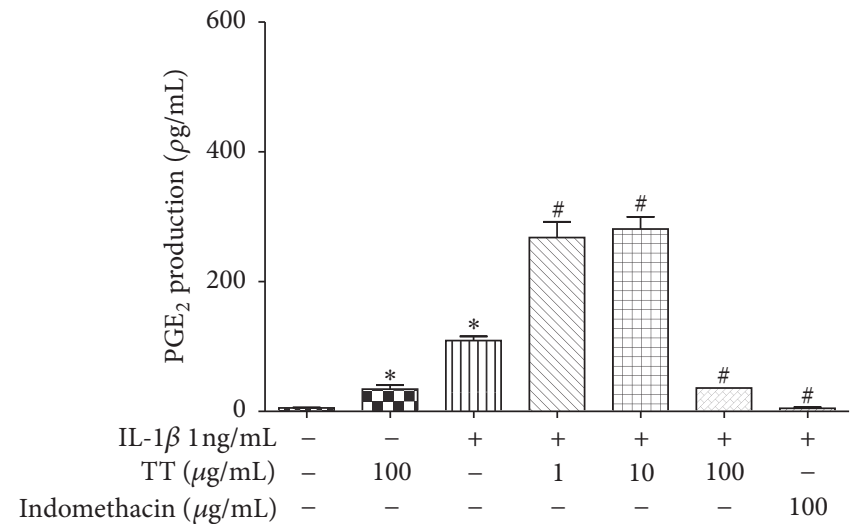

(f)

Figure 6: The effects of HRF (a) and its components: Harrisonia perforata Merr. (HP), Capparis micracantha DC. (CM), Clerodendrum petasites S. Moore (CP), Ficus racemosa L. (FR), and Tiliacora triandra Diels (TT) (b-f) on COX activity in the presence of exogenous AA in IL- $1 \beta$-treated HUVECs. The data represent mean \pm SEM of three experiments. Control: nonaddition. ${ }^{*} p<0.05$, versus control group; ${ }^{\#} p<0.05$, versus IL- $1 \beta$ only.

inhibitory activity against both COX-1 and 5-LOX in vitro [19].

Our findings provide preliminary evidence that HRF and its components can modulate the COX enzymes directly involved with $\mathrm{PGE}_{2}$ production in IL-1 $\beta$-induced in HUVECs (Figure 7).
However, further studies to elucidate HRF's pharmacological effects and other signaling pathways involving its antiinflammatory and antipyretic potentials should be investigated to support its traditional usage and clinical application and to develop HRF as a novel antipyretic agent in the future. 

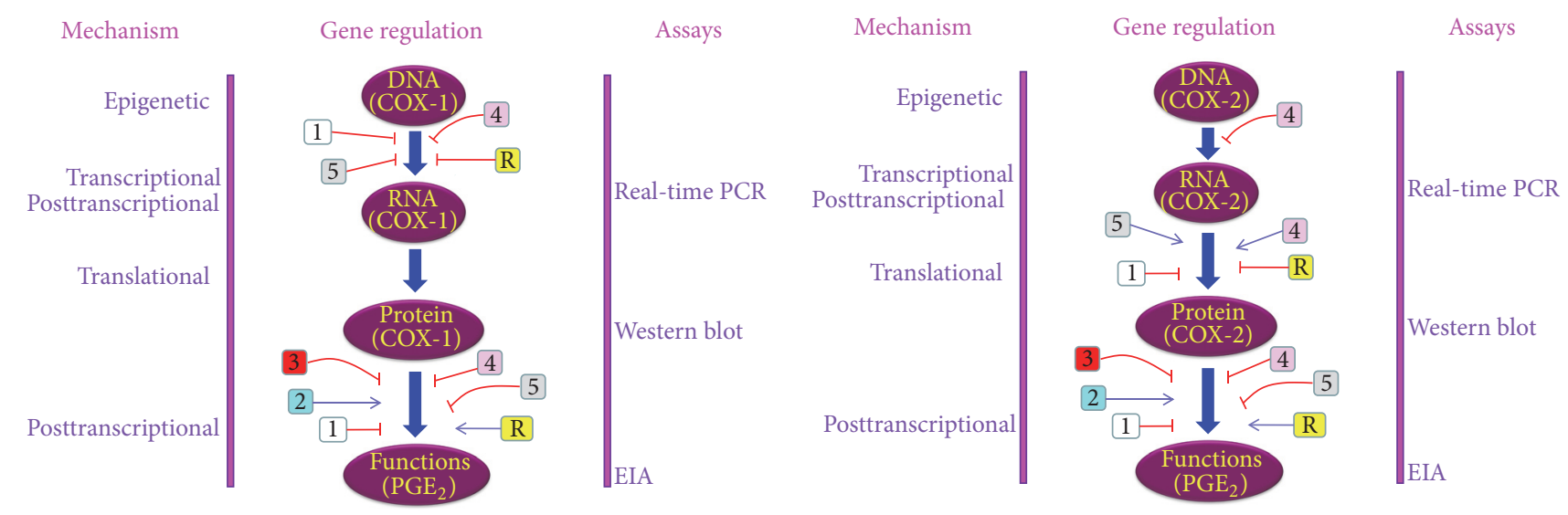

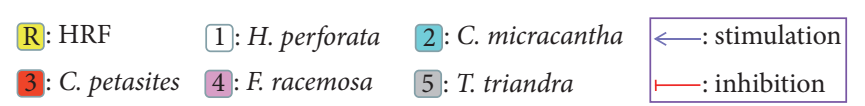

(a) $\begin{array}{llll}\text { R: HRF } & \text { 1: }: \text {. perforata } & \text { 2: C. micracantha } & \longleftarrow: \text { stimulation } \\ \text { 3: C. petasites } & 4: \text { : racemosa } & \text { 5: T. triandra } & \longleftarrow: \text { inhibition }\end{array}$

(b)

FIGURE 7: Summary of the effects of HRF and its components on COX-1 (a) and COX-2 (b) gene regulation pathway in HUVECs.

\section{Ethical Approval}

The protocol of this study was approved by the Ethics Committee on Research Involving Human Subjects, Faculty of Medicine, Mahidol University (EC no. Si412/2011).

\section{Conflicts of Interest}

The authors declare that there are no conflicts of interest.

\section{Acknowledgments}

This research was supported by the Thailand Research Fund (Grant no. DBG5380040) and the Chalermphrakiat Grant, Faculty of Medicine, Siriraj Hospital, Mahidol University.

\section{References}

[1] L. M. Harden, S. Kent, Q. J. Pittman, and J. Roth, "Fever and sickness behavior: friend or foe?" Brain, Behavior, and Immunity, vol. 50, pp. 322-333, 2015.

[2] S. S. Evans, E. A. Repasky, and D. T. Fisher, "Fever and the thermal regulation of immunity: The immune system feels the heat," Nature Reviews Immunology, vol. 15, no. 6, pp. 335-349, 2015.

[3] C. Cao, K. Matsumura, K. Yamagata, and Y. Watanabe, "Endothelial cells of the rat brain vasculature express cyclooxygenase- 2 mRNA in response to systemic interleukin$1 \beta$ : A possible site of prostaglandin synthesis responsible for fever," Brain Research, vol. 733, no. 2, pp. 263-272, 1996.

[4] M. G. Netea, B. J. Kullberg, and J. W. M. Van der Meer, "Circulating cytokines as mediators of fever," Clinical Infectious Diseases, vol. 31, no. 5, pp. S178-S184, 2000.

[5] C. A. Dinarello, J. G. Cannon, and S. M. Wolff, "New concepts on the pathogenesis of fever.," Reviews of Infectious Diseases, vol. 10, no. 1, pp. 168-189, 1988.
[6] A. Shah, E. Unger, M. D. Bain et al., "Cytokine and adhesion molecule expression in primary human endothelial cells stimulated with fever-range hyperthermia," International Journal of Hyperthermia, vol. 18, no. 6, pp. 534-551, 2002.

[7] C. A. Dinarello, "Infection,fever, and exogenous and endogenous pyrogens: some concepts have changed," Journal of Endotoxin Research, vol. 10, no. 4, pp. 201-222, 2004.

[8] J. R. Vane, Y. S. Bakhle, and R. M. Botting, "Cyclooxygenases 1 and 2," Annual Review of Pharmacology and Toxicology, vol. 38, pp. 97-120, 1998.

[9] E. Ricciotti and G. A. Fitzgerald, "Prostaglandins and inflammation," Arteriosclerosis, Thrombosis, and Vascular Biology, vol. 31, no. 5, pp. 986-1000, 2011.

[10] C. D. Funk, "Prostaglandins and leukotrienes: advances in eicosanoid biology," Science, vol. 294, pp. 1871-1875, 2001.

[11] J. A. Mitchell, P. Akarasereenont, C. Thiemermann, R. J. Flower, and J. R. Vane, "Selectivity of nonsteroidal antiinflammatory drugs as inhibitors of constitutive and inducible cyclooxygenase," Proceedings of the National Acadamy of Sciences of the United States of America, vol. 90, no. 24, pp. 11693-11697, 1993.

[12] D. L. Simmons, D. Wagner, and K. Westover, "Nonsteroidal antiinflammatory drugs, acetaminophen, cyclooxygenase 2, and fever," Clinical Infectious Diseases, vol. 31, pp. S211-S218, 2000.

[13] D. Bjorkman, "Nonsteroidal anti-inflammatory drugassociated toxicity of the liver, lower gastrointestinal tract, and esophagus," American Journal of Medicine, vol. 105, no. 5 A, pp. 17S-21S, 1998.

[14] R. Asero, "Single NSAID hypersensitivity is associated with atopic status," European Annals of Allergy and Clinical Immunology, vol. 47, no. 2, pp. 48-53, 2015.

[15] T. Pluemsamran, P. Tripatara, R. Phadungrakwittaya, P. Akarasereenont, T. Laohapand, and U. Panich, "Redox mechanisms of AVS022, an oriental polyherbal formula, and its component herbs in protection against induction of matrix metalloproteinase-1 in UVA-irradiated keratinocyte HaCaT cells," Evidence-Based Complementary and Alternative Medicine, vol. 2013, Article ID 739473, 10 pages, 2013. 
[16] T. Juckmeta and A. Itharat, "Anti-inflammatory and antioxidant activities of thai traditional remedy called "ya-ha-rak"," Journal of Health Research, vol. 26, no. 4, 2012.

[17] A. Konsue, J. Sattayasai, P. Puapairoj, and C. Picheansoonthon, "Antipyretic effects of Bencha-Loga-Wichien herbal drug in rats," Thai Journal of Pharmacology, vol. 29, no. 1, pp. 79-82, 2008.

[18] A. Panthong, D. Kanjanapothi, T. Taesotikul, T. Wongcome, and V. Reutrakul, "Anti-inflammatory and antipyretic properties of Clerodendrum petasites S. Moore," Journal of Ethnopharmacology, vol. 85, no. 1, pp. 151-156, 2003.

[19] R. W. Li, D. N. Leach, S. P. Myers, G. D. Lin, G. J. Leach, and P. C. Waterman, "A new anti-inflammatory glucoside from ficus racemosa L.," Planta Medica, vol. 70, no. 5, pp. 421-426, 2004.

[20] R. B. Rao, K. Anupama, K. R. L. A. Swaroop, T. Murugesan, M. Pal, and S. C. Mandal, "Evaluation of anti-pyretic potential of Ficus racemosa bark," Phytomedicine, vol. 9, no. 8, pp. 731-733, 2002.

[21] P. Akarasereenont, K. Techatraisak, S. Chotewuttakorn, and A. Thaworn, "The expression of cyclooxygenase- 2 in human umbilical vein endothelial cell culture from preeclampsia," Journal of the Medical Association of Thailand, vol. 82, no. 2, pp. 167-171, 1999.

[22] T. Mosmann, "Rapid colorimetric assay for cellular growth and survival: application to proliferation and cytotoxicity assays," Journal of Immunological Methods, vol. 65, no. 1-2, pp. 55-63, 1983.

[23] C. A. Dinarello, S. Gatti, and T. Bartfai, "Fever: Links with an ancient receptor," Current Biology, vol. 9, no. 4, pp. R147-R150, 1999.

[24] K. Seibert, Y. Zhang, K. Leahy et al., "Pharmacological and biochemical demonstration of the role of cyclooxygenase 2 in inflammation and pain," Proceedings of the National Acadamy of Sciences of the United States of America, vol. 91, no. 25, pp. 12013-12017, 1994.

[25] D. L. Simmons, R. M. Botting, and T. Hla, "Cyclooxygenase isozymes: the biology of prostaglandin synthesis and inhibition," Pharmacological Reviews, vol. 56, no. 3, pp. 387-437, 2004.

[26] A. Bonazzi, M. Bolla, C. Buccellati et al., "Effect of endogenous and exogenous prostaglandin E2 on interleukin- $\beta$-induced cyclooxygenase-2 expression in human airway smooth-muscle cells," American Journal of Respiratory and Critical Care Medicine, vol. 162, no. 6, pp. 2272-2277, 2000.

[27] P. Akarasereenont, K. Techatrisak, S. Chotewuttakorn, and A. Thaworn, "The induction of cyclooxygenase- 2 in IL- $1 \beta$-treated endothelial cells is inhibited by prostaglandin E2 through cAMP," Mediators of Inflammation, vol. 8, no. 6, pp. 287-294, 1999.

[28] M. E. Turini and R. N. DuBois, "Cyclooxygenase-2: a therapeutic target," Annual Review of Medicine, vol. 53, pp. 35-57, 2002.

[29] D. Plasen, "The roles of cyclooxygenase and nitric oxide synthase on acute effects of lipid component activated endothelial cells," 2001.

[30] A. Zarghi and S. Arfaei, "Selective COX-2 inhibitors: a review of their structure-activity relationships," Iranian Journal of Pharmaceutical Research, vol. 10, no. 4, pp. 655-683, 2011.

[31] P. Deep, M. T. Ansari, A. K. Singh, and P. Raghav, "Pharmacological Potentials of Ficus racemosa - a Review," Journal of Pharmaceutical Sciences Review and Research, vol. 22, no. 1, pp. 29-34, 2013. 


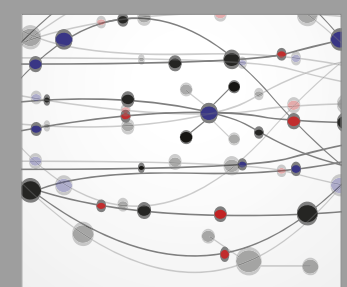

The Scientific World Journal
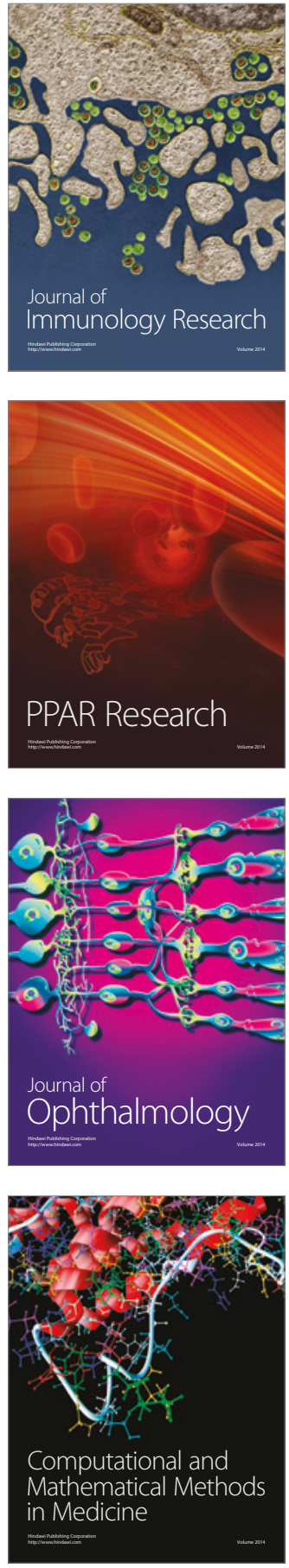

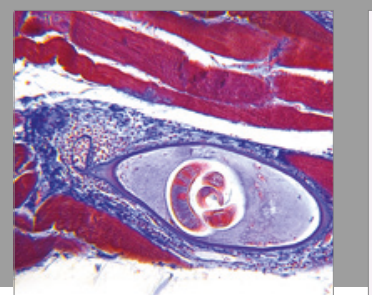

Gastroenterology Research and Practice
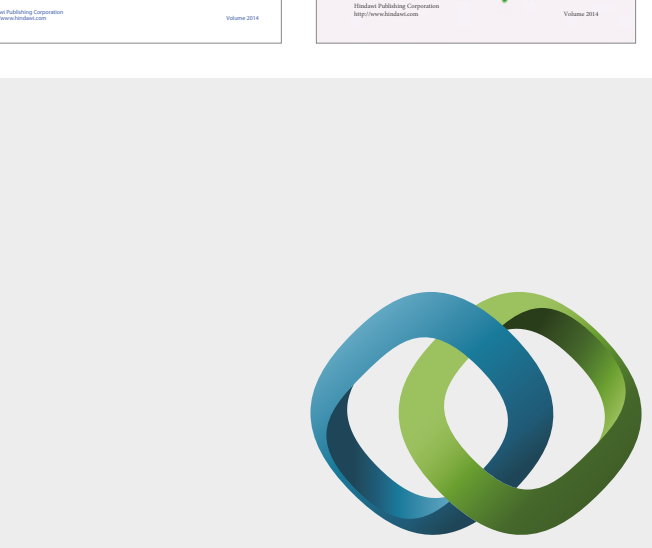

\section{Hindawi}

Submit your manuscripts at

https://www.hindawi.com
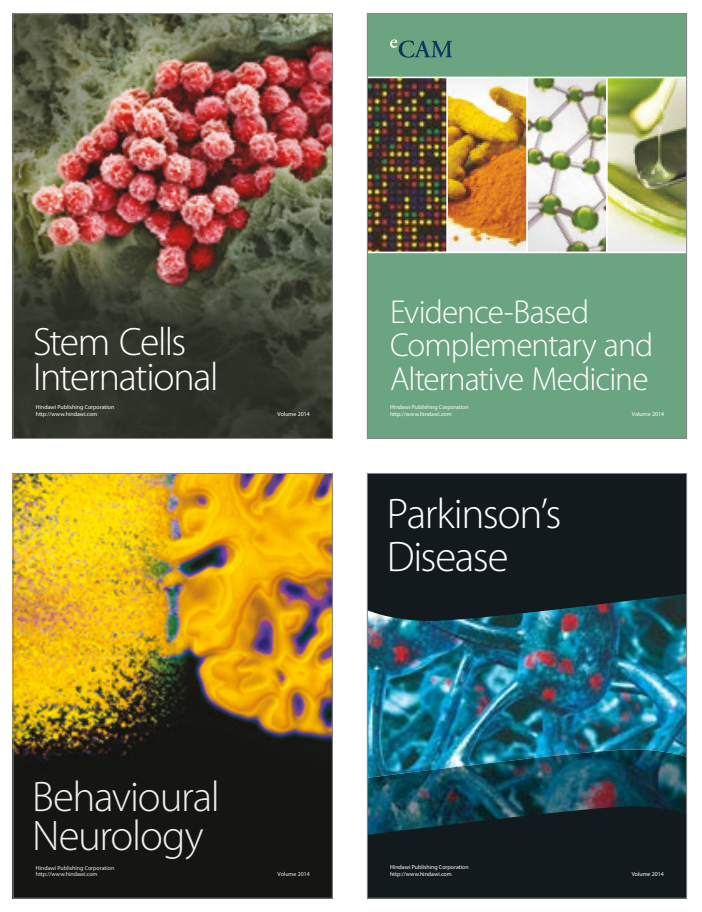
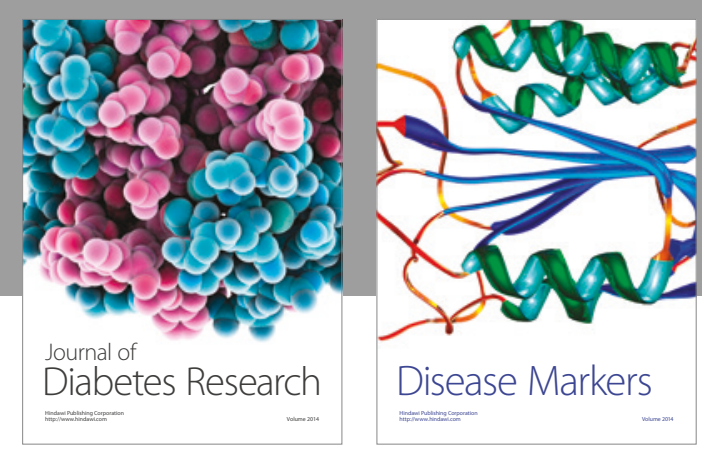

Disease Markers
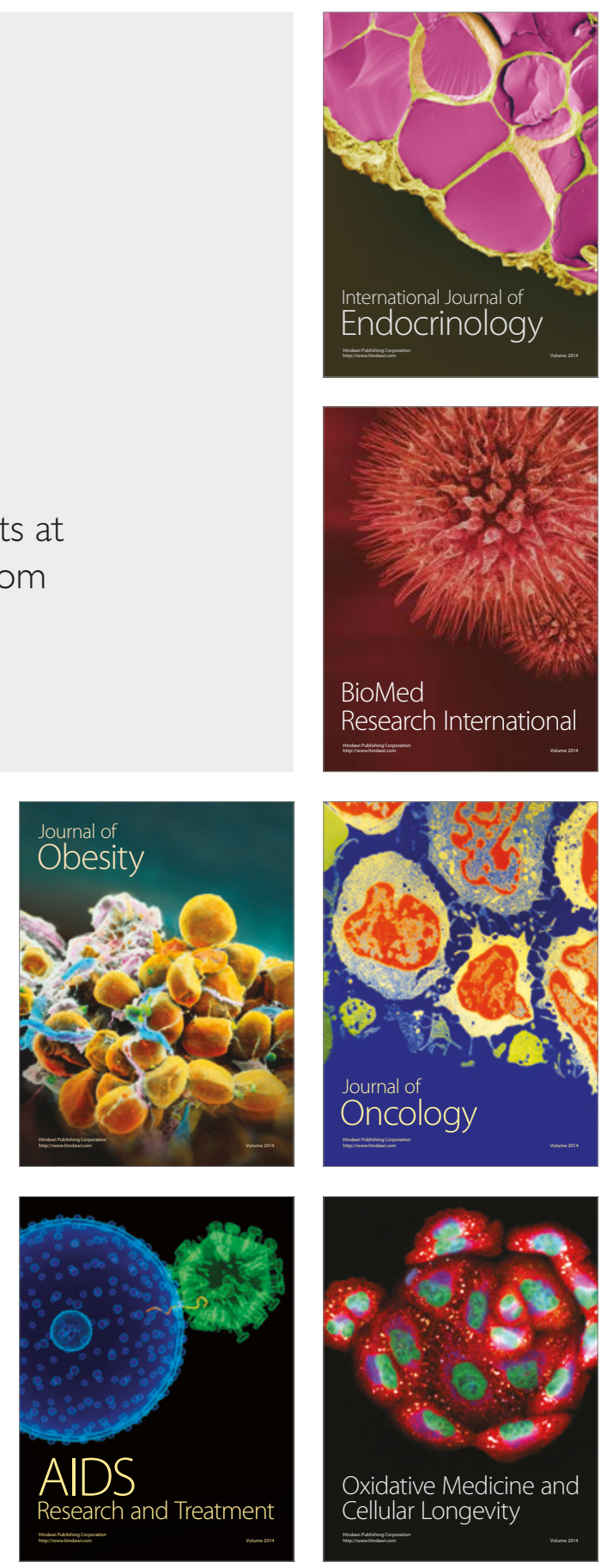